\title{
Hubris and Nemesis in Heads of Government
}

\author{
Lord David Owen
}

J R Soc Med 2006;99:548-551

This article is based on David Owen's new book 'In Sickness and in Power', which is due to be published by $W W$ Norton in the autumn of 2007.

Ever since I began to lecture and write about illness in Heads of Government four years ago, ${ }^{1}$ I have been struck by the mismatch between what the press and public see as mental illness amongst their leaders and what the medical profession are ready to diagnose as mental illness.

When the press and public use terms like madness, lunacy, psychopath, megalomania or hubris, to describe the conduct of Heads of Government as diverse as Adolf Hitler, Idi Amin, Chairman Mao, Robert Mugabe, Slobodan Milosevic or Saddam Hussein, they are using words which the medical profession has either long abandoned, redefined or severely restricted. Madness and lunacy for doctors are terms which have been totally replaced by defined mental disorders. Psychopathic behaviour has been narrowed into anti-social personality disorder, and megalomania to delusions of grandeur. In most cases, Heads of Government such as these are not considered to have any mental illness by the medical profession.

Yet when the medical profession diagnose some popular Heads of Government as having a serious mental illness the public can find this hard to accept. Many British people resist the label of Bipolar Disorder being applied to their hero Winston Churchill when Prime Minister. They can accept that his own description of his 'Black Dog' was a depressive illness, but they are less convinced that he ever had episodes of mania. Similarly, in America, when a recent paper by three psychiatrists claimed that Abraham Lincoln, Theodore Roosevelt and Lyndon Johnson had Bipolar Disorder while President, ${ }^{2}$ few would have denied that they had had depressive illnesses, but questions are raised as to whether there were specific episodes of mania. People sense that these larger-than-life, volatile figures were exceptional and not easily medically classifiable.

Two British physicians claimed Saddam Hussein was under treatment with Lithium for bipolar disorder and that he had suffered two depressive episodes, one during Iraq's eight-year war with Iran and the other in the autumn of $1990 .^{3}$ Yet at no time during Saddam

House of Lords, London SW1A OPW, UK

E-mail: lordowen@nildram.co.uk
Hussein's trial in Iraq in 2005/2006 has he used mental illness as a mitigating factor in his defence, nor did the Iraqi Special Tribunal show any interest in exploring any mental illness.

In the case of Hitler, people persist - despite medical refutation -in thinking of Hitler as mad. A wartime psychoanalytical study ${ }^{4}$ predicted that Hitler would commit suicide, and this reinforces the layman's belief that he was mad because suicide is associated in their mind with mental illness. No label, even that of evil, can fully explain Hitler's character. Yet the titles of the two volumes that make up Kershaw's impressive biography of Hitler ${ }^{5}$ - Hubris and Nemesis - provide a powerful insight.

\begin{abstract}
Hubris and Nemesis
Hubris denotes over confidence, exaggerated pride. It can be associated with a lack of knowledge or interest in history, also with shaming or contempt of others.

Nemesis is the goddess of retribution and denotes the destruction, suffering or punishment that can follow in the
\end{abstract} wake of hubris.

Someone who knew Franklin Roosevelt, a US President who died early into his fourth term, wrote 'The problem of restraining power has always been the central problem of government . . . Power is dangerous. It grows by what it feeds upon, dulling the perception, clouding the vision, imprisoning its victim, however well-intentioned he may be, in that chill of isolation of a self-created aura of intellectual infallibility which is the negative of the democratic principle.' 6

The British Prime Minister, Margaret Thatcher (19791990), was a single-minded and assertive leader. She appeared fit and well throughout her term in office, apart from a detached retina in her eye. Margaret Thatcher's hubris built up during her Prime Ministership into fullblown hubris in her attitudes to the European Community. On 30 October 1990 she returned to the House of Commons after the Rome European Heads of Government meeting, where in answer to questions, 'it became in its monosyllabic brutality, the rubric of one of her most famous parliamentary moments, leaping with rage, ringing round the chamber, startling even those who in eleven years 
had much experience of the Thatcher vocabulary on Europe. "No . . . no . . . no," she bawled, her eye seemingly directed to the fields and seas, the hills and the landing-grounds, where the island people would never surrender.' 7

The hubristic posture has been described by the philosopher, David E Cooper, as 'excessive self-confidence, an "up yours!" attitude to authority, pre-emptive dismissal of warnings and advice, taking oneself as a model. ${ }^{\prime}$ This wording brings to mind the famous headline in the Sun newspaper about the then President of the European Commission, Jacques Delors: 'Up Yours Delors'. Though not written by Margaret Thatcher, it was a sentiment inspired by her. Her hubris found expression through exaggerating her prejudices and in contempt for the views of her colleagues. It developed into incompetence over the Poll Tax. She retained her self-discipline in public until the moment of leaving Downing Street for the last time, when inside her car tears welled up and the Iron Lady was seen to crack. A leader who had won three General Elections was removed, not by the nation's voters but, within the rules that safeguard a parliamentary democracy, by her own MPs. She and her friends preferred to categorize it as treachery and referred to it as a political assassination.

The Jungian analyst, James Hillman, argues that normally hubris is limited by self-control. 'The limiting effect of one's innate image prevents that inflation, that trespassing or hubris that the classical world considered the worst of human errors. In this way character acts as a guiding force.' 9

The centralizing nature of US President George W Bush and the British Prime Minister Tony Blair was such that they were both in search of more power and were therefore particularly susceptible to being swept up with the intoxication of power, following the tragic events of September 2001 in New York and Washington, referred to as $9 / 11$. The war against terrorism was sponsored by Bush and designed by Cheney. It was the opportunity to strengthen the powers of the President. It was modern hubris, described by Daniel Bell as 'the refusal to accept limits, the insistence on continually reaching out. The modern world proposes a destiny that is always beyond: beyond morality, beyond tragedy, beyond culture.' ${ }^{10}$ Bush and Blair began 'trying to create a new legal regime' 11 for avoiding the constraints of international and national law on interrogation and detention after their military intervention in Afghanistan and later Iraq. They planned to build a 'new paradigm' 12 to replace the Geneva Conventions that were not allowed to apply to al-Qaeda or Taliban prisoners, ${ }^{13}$ and they tried to do all this by themselves, with little or no consultation with friends or allies.

Blair, after winning a second General Election two months prior to $9 / 11$, in the flush of victory, with no parliamentary scrutiny, formally changed the whole basis of Cabinet government as it had related to foreign and defence matters. The new structure was deliberately designed by Blair to ensure he could exercise, over international policy, much the same powers as President Bush in the White House. The key officials and their staff on foreign and defence policy and the European Union were brought into the political hothouse atmosphere inside 10 Downing Street in two new Secretariats ${ }^{14}$ to service the Prime Minister politically and strategically, rather than the Cabinet. Much the same was done with the Joint Intelligence Committee, in terms of its working arrangements if not in terms of its formal structure. The consequence was a lack of objectivity, probity and collectivity over the handling of the invasions of Afghanistan and Iraq.

Of course the most important determinants of the wars in Afghanistan and Iraq lay in Washington. London and the British Prime Minister's role were of far less importance. Experienced officials questioned whether Blair was deluding himself about his relationship with Bush. They worried about the lack of substance in the Bush-Blair dialogue and about the extent of the mutual posturing. At the G8 meeting in St Petersburg in July 2006, the world was able to hear, due to a microphone having been left switched on, how the two men talked to each other. This 'Yo, Blair' conversation was demeaning, and an example of Blair showing his obsession with what he once called 'eyecatching initiatives'.

There have been incompetent Heads of Government in the past who have shown no signs of hubris and have often lacked for self-confidence. But there is an acknowledged association between hubris and incompetence in Iraq mentioned by a number of serious commentators. ${ }^{15}$ The restless energy of hubris that constantly intervenes does so, often without all the factual information; the excessive selfconfidence that does not seek advice or fails to listen to the wisdom of others, makes serious mistakes; and the inattention to detail and focus on the broad brush all combine to associate hubris with incompetence and poor judgement.

In addition to having this tendency towards incompetence, both Bush and Blair share strong religious beliefs and have an inner certainty that they are men of destiny. Unusually - perhaps because he knew he was committed to stepping down as Prime Minister before another General Election - on 4 March 2006, on television, Blair abandoned his reservations on talking about his religion in public and, in relation to Iraq, said, 'If you have faith about these things then you realize that judgement is made by other people. If you believe in God, it's made by God as well.'

Much has been written about leaders all through the centuries who claim to have a special relationship with a power outside themselves. The wiser the leader the more 
likely they are to keep such beliefs private. The secular state reinforces the view that these matters are best kept out of the public sphere. What we have the right to demand of our leaders, particularly when contemplating going to war, is rational, factual weighing of the risks, and the benefits, before resorting to military force. Holy wars breed arrogance, ignite hubris and are followed all too often by nemesis. There is a public wariness and scepticism about bringing religion into questions of peace or war, just as there is a dislike of personal narcissism and egotism from civilian leaders when it is the armed forces who are risking their lives.

Being psycho-analysed is not new for a political leader. Freud wrote a book about Woodrow Wilson. Blair had a book written about him from a psychoanalytical standpoint by Leo Abse, a former Labour MP. Initially Abse's analysis of the impact of Blair's childhood was dismissed but increasingly it has been given greater regard. ${ }^{16}$ One of the analytical books on Bush is by Dr Justin Frank. He claims megalomania and mania exhibit three overtly similar defensive characteristics: control, contempt and triumph. 'A manic person wants to repair the damage he's caused, once he recognizes it. He feels guilt. The megalomaniac is indifferent to any damage he caused, because he had a reason for his actions; he is without guilt or compassion, and incapable of even thinking about making reparation. ${ }^{17}$

Henry Kissinger, presciently, said in 1999 to the World Affairs Council, 'In America, there has been a tendency to divide foreign policy into two schools of thought. One that identifies foreign policy as a subdivision of psychiatry and another that treats it as a subdivision of theology.' Bush and Blair are in these terms theologians. International statesmen dealing with nations need to be more than theologians or psychiatrists. They need to be ready to practice all the skills of diplomacy. This requires a readiness to talk and listen patiently over sometimes long periods of time, to tolerate the frustration that it inevitably produces, but also to know when to use power to influence the debate and dialogue. To know when to threaten or invoke sanctions, political or economic, and when force of arms have to be brought to bear.

Following 9/11, in January 2002, Blair flew in to Kabul having held 54 meetings with foreign leaders and having flown more than 40000 miles on some 31 separate flights. He had pursued a frenetic schedule. He was chronically short of sleep and despite a holiday in Egypt was exhausted, mentally and physically. ${ }^{18} \mathrm{He}$ tried to keep up the same pace through 2002 and much of 2003. Bush was more disciplined than Blair in how he handled his schedule, insisting on having enough time to sleep, and appeared less frenzied. But the language and rhetoric of both men began to have the ring of zealotry, nuance and qualification became rarer, certainty and simplicity became ever more dominant.

It is important, for those who believe in the decisive leadership of representative democracies, to analyse the nature of Blair and Bush's incompetent leadership and its links to hubris. They did not lack courage in deciding to invade Iraq. What they lacked were the skills and attention to detail to foresee and plan for all the possible scenarios that would face the military they ordered into battle. I am not attracted to conspiracy theories. I supported the invasion of Iraq and I do believe, in contrast to many of their critics, that Bush and Blair did think gas and chemical weapons could be found inside Iraq in 2003, as did the intelligence services of France, Russia and Israel. They genuinely did fear that these weapons might be used, as gas had been previously used against Iran. They also dreaded the eventual development of Iraqi nuclear weapons.

Yet they did not seal the Iraqi borders with Syria and Iran after the invasion, even though the opportunism of al-Qaeda meant their involvement in Iraq was totally predictable. They did not plan in detail for what exactly would replace the authority of Saddam Hussein. Nor did they think through the consequences of disbanding the Iraqi Army. Why? Excessive self-confidence convinced them that the troops would be welcomed with open arms and they were dismissive of the genuine concerns of advisers.

For President Bush on 1 May 2003 to fly on to the aircraft carrier Abraham Lincoln off the coast of California with the control tower emblazoned with 'Mission Accomplished' to celebrate victory in Iraq was hubris of a very high order. It was also demeaning in view of the slogan's patent absurdity. Even Rumsfeld argued successfully against Bush using the phrase in his speech. Blair never went so far but his early rhetoric was also far too triumphant. Even when the insurgency developed, neither man was ready to admit error and authorize the extra troops needed. As a key US official in Baghdad said, 'Hubris and ideology ruled.' 19 Competently handled, the US/UK invasion of Iraq could have laid the foundation for a unified democratic Iraq. Incompetently handled, it has led to a civil war and possibly partition.

Tony Blair's judgements covering Afghanistan and Iraq showed signs of being not only erroneous, but unstable and unstructured. Whether because he was depressed, very stressed, felt he should go, or a combination of all three, Blair apparently decided to step down as Prime Minister around late May/early June of 2004 but was dissuaded from doing so by some of his loyal friends in the Cabinet. A family friend, Lord Melvyn Bragg, admitted in public that Blair had been under tremendous stress, saying in September 2004, 'in my view the real stress was personal and 
family, which matters most to him. ${ }^{20}$ By the time the Labour Party Conference came around, however, Blair, had not only changed his mind about stepping down but he publicly indicated, on 30 September 2004, that he was staying on to fight the next Election, adding something that he greatly regretted saying: that he would not fight the following one. At that moment Blair knew that two days later, on 1 October, he would be having a catheter ablation for his heart condition, atrial flutter, and he needed to pre-empt speculation about stepping down on health grounds before the Election.

On 14 July 2006 the Financial Times ran an article entitled, 'Hubris is the thread running through Blair's many travails.' After his handling of the Lebanon crisis, nemesis struck. Blair was told by Labour MPs that they were no longer ready to let him stay as Prime Minister beyond June 2007 and many wanted him gone before then.

The most common criticism of Blair has been that he was Bush's poodle and simply went along with the Bush Administration at all times. Common it may be, but it is not the right criticism. Blair actually agreed with Bush on most of the decisions which are now seen to be wrong. What we have witnessed should be a solemn warning. The intoxication of power, not just illness in Heads of Government, can be as great a menace to the quality of their leadership as are conventional illnesses.

In the 21 st century we are likely to see significant advances in cognitive neuroscience. A breed of drugs called cognition enhancers ${ }^{21}$ has already been shown to enhance the performance of the brain by improving short term memory and increasing the speed of thought. President Bush's brother, Neil, is reported to have dyslexia. There is a well-established association between dyslexia and attention deficit hyperactivity disorder (ADHD), which itself is a lifelong disorder. Recent genetic studies in ADHD patients with reading disabilities point to possible adrenergic mechanisms. ${ }^{22}$ No basis for hubris has yet been found in neuroscience and no linkage may ever be found. Yet watching the changes in the new sciences of the mind in my lifetime, I believe hubris will be found to have an explanation in neuroscience. Meanwhile, we must assume that hubris may never be curbed or cured by doctors and only constant vigilance and the countervailing power of an active, probing and well-informed democracy will prevent it continuing to damage decision making amongst Heads of Government.

Competing interests None declared.

\section{REFERENCES}

1 Owen D. Diseased, demented, depressed: serious illness in Heads of State. QJ Med 2003;96:325-36; and The Effect of Prime Minister Anthony Eden's illness on his decision making during the Suez Crisis. QJ Med 2005;98:1-16

2 Davidson JRT, Connor KM, Swartz M. Mental illness in US Presidents between 1776 and 1974 -a review of biographical sources. J Nerv Ment Dis 2006;194:47-51

3 L'Etang H. Ailing Leaders in Power, 1914-1994. London: Royal Society of Medicine Press, 1995:66

4 Langer WC. The Mind of Adolf Hitler, The Secret Wartime Report. New York: Basic Books, 1972

5 Kershaw I. Hitler 1880-1936 Hubris and Hitler 1936-1945 Nemesis. London: Penguin Press History, 1998 and 2000

6 Park BE. The Impact of Illness on World Leaders. Philadelphia: University of Pensylvannia Press, 1986:280-1

7 Young H. The Blessed Plot. Britain and Europe from Churchill to Blair. Oxford: Macmillan, 1998:368

8 Cooper DE. The Measure of Things: Humanism, Humility and Mystery. Oxford: Oxford University Press, 2002:163

9 Hillman J. The Force of Character. New York: Ballantine Books, 1999: 178

10 Bell D. The Cultural Contradictions of Capitalism. New York: Basic Books, 2006:48-9

11 Yoo J, US Deputy Assistant Attorney General, 2002

12 Gonzales A, US Attorney General

13 Urquhart B. The Outlaw World. New York Review of Books, 11 May 2006

14 Owen D. The Ever Growing Dominance of No 10 in British Diplomacy since 1982. LSE Foreign Secretary Series Programme of Lectures, 8 October 2003. Extract also carried by Prospect Magazine, 'Two-Man Government', December 2003

15 Schlesinger A, Jr. Oppoertunity knocks: it may look grim now, but the Republicans' hubris and incompetence will ultimately prove their undoing. The American Prospect, 2004; Freedland J. The blind prophet. Guardian, 2003; Kupchan CA, Takeyh R. Middle East: reaping what Bush sowed. International Herald Tribune, 2006; and Ricks TE. Fiasco, The American Military Adventure in Iraq. London: Penguin Press, 2006

16 Abse L. Tony Blair: The Man Behind the Smile. Revised edition. London: Robson Books, 2003

17 Frank JA. Bush on the Couch. Inside the Mind of the US President. London: Politico's Publishing, 2006:202

18 Scott P. Tony \& Cherie, A Special Relationship. London: Sidgwick and Jackson, 2005:219

19 Blumenthal S. How Bush Rules. Chronicles of a Radical Regime. Princeton, NJ: Princeton University Press, 2006:89

20 Scott P. Tony \& Cherie, A Special Relationship. London: Sidgwick and Jackson, 2005:227

21 Farah MJ, Illes J, Cook-Deegan R, et al. Neurocognitive enhancement. What can we do and what should we do? Nat Rev Neurosci 2004; 5:421-5

22 Pennington BF. From single to multiple deficits models of developmental disorders. Cognition 2006;101:390-3; and Stevenson J, Langley $\mathrm{K}$, Pay $\mathrm{H}$, et al. Attention deficit hyperactivity disorder with reading disabilities: preliminary genetic findings on the involvement of the ADRA2A gene. J Child Psychol Psychiatry 2005; 46: $1081-8$ 